\title{
KEARIFAN BUDAYA LOKAL DALAM PENGUTAN TRADISI MALEMANG DI TENGAH MASYARAKAT MODERNISASI DI SUNGAI KERUH MUSI BANYUASIN SUMATERA SELATAN ${ }^{1}$
}

\author{
Dendi Sutarto \\ Dosen Tetap Program Studi Ilmu Pemerintahan \\ Fakultas Ilmu Sosial Ilmu Politik Universitas Riau Kepulauan Batam \\ dendi_sutarto@yahoo.co.id
}

\begin{abstract}
This research aim at explaining to the Malemang tradition is one of the local cultural heritage of the archipelago very unique living today is Malemang tradition is a traditional community unique in the Sungai Keruh district Musi Banyuasin South Sumatra, this tradition is characterized by burning lemang morning by every population in the Kertayu village. This tradition originated from local communities for resisting disaster when the Dutch colonial era outbreaks of a disease so the tradition of resisting disaster dimension mystic is done with a series of indigenous tradition that connects the tradition Malemang, thanksgiving after the harvest the tomb of Puyang Burung Jauh and the concept of salvation, as well as religious and cultural acculturation locally very strong value system of solidarity, social cohesion, harmony, peace, and social empathy which became part of the social system culture, norms, and religion. But the times entered into a cultural struggle modernization occurred between local culture and traditions of modernization that tends to undermine the foundations of the social and cultural systems has been the pattern of action and community tradition over the years. In this study using the methodology of qualitative descriptive with approach of sociology of cultural assisted to the theory of functionalism strukturalime and social change as analysis the dynamics of the struggle between the cultural wisdom, Malemang traditions particularly in strengthening the existence in society modernization. This study resulted in that the cultural influence of modernization is very rational, capitalism, hedonism, consumerism and the stream of Western culture to Indonesia have an impact on the destruction of the foundations of the system of culture, norms, tradition so that changes in behavior patterns of society from the value of local knowledge as a social system culture that gives directions foothold in the act. Additionally began abandoning the old culture that are considered irrelevant to the modernity of the times, to address the issue of indigenous peoples should have as a cultural mechanisms to strengthen local wisdom.
\end{abstract}

Keyword: local wisdom, malemang tradition, modernisation, and social change

\footnotetext{
${ }^{1}$ Disari dari makalah penulis yang di sampaikan pada Seminar Kepemimpinan Kepemudaan Madya Kementrian Pemuda dan Olahraga RI - PUSKAKEM Universitas Sriwijaya di Hotel Aston Palembang, 2-6 Oktober 2012, dan hasil penelitian mandiri penulis 2013-2014.
} 


\section{Latar Belakang Masalah}

Masyarakat Indonesia dewasa ini dengan keberagaman suku, budaya dan tradisi lokal yang dimiliki sangat kaya akan nilai-nilai luhur dan beragam tradisi yang tidak ternilai harganya. Perbedaan suku bangsa, adat, dan kedaerahn sering disebut sebagai ciri khas masyarakat Indonesia yang bersifat majemuk. Istilah majemuk merupakan termilonogi yang diperkenalkan oleh Furnivall pada masa Hindia Belanda sebagai deskripsi masyarakat Indonesia yang majemuk (plural society) yaitu suatu masyarakat yang terdiri atas dua atau lebih elemen yang hidup sehari-hari tanpa ada pembauran satu sama lain dalam politik, dan secara sosial masyarakat sangat kompleks yang terbagai kedalam segmentasi bentuk dan pola kehidupan sosial, baik tradisi, suku, geografis, ekonomi, agama dan budaya (Nasikun, 2010)

Keberagaman budaya dan tradisi lokal di Indonesia yang merupakan ekspresi simbolik, sekaligus wujud akulturasi agama, etnik dan budaya lokal. Aspek agama memberikan warna yang cukup besar dalam pembentukan tradisi lokal, seperti dalam pandangan Clifford Geertz yang melihat agama sebagai suatu sistem kebudayaan (Parsudi Suparlan; 1983). Salah satu ekspresi akulturasi busaya lokal dan sekaligus pluralitas budaya dan tradisi masyarakat Indonesia yaitu tradis Malemang yang terdapat di desa Kertayu kecamatan Sungai Keruh Kabupaten Musi Banyuasin Sumatera Selatan. Tradisi Malemang merupakan tradisi adat tahunan yang sangat unik dilaksanakan pasca panan padi yang pada awalnya menurut penulis, tradisi ini secara historis lahir dari tiga aspek penting yaitu agama (simbol sistem keyakinan), pola kehidupan petani, dan kolonialisme dimana proses panjang kehidupan sosial pergulatan ketiga aspek itu berkembangan menjadi tradisi yang kompleks seiring perubahan sosial budaya dan moderniasi yang begitu kuat.

Tradisi Malemang merupakan tradisi adat yang khas di masyarakat kecamatan Sungai Keruh Musi Banyuasin, tradisi ini bercirikan pembakaran lemang $^{2}$ dipagi hari oleh setiap penduduk di desa Kertayu. Tradisi ini berawal dari upaya masyarakat setempat untuk menolak balak ketika zaman kolonial terjadi wabah penyakin, sehingga tradisi tolak balak yang berdimensi mistik itu dilakukan dengan rangkaian adat tradisi yang menghubungkan antara tradisi Malemang, syukuran pasca panen, makam Puyang Burung Jauh, dan konsep keselamatan, serta terjadinya akulturasi agama dan budaya lokal.

\footnotetext{
${ }^{2}$ Lemang yaitu ketan merah dan putih dengan rasa asin dan manis yang dimasukan ke dalam bambu seukuran lengan tangan orang dewasa, dan juga menggunakan bambu kecil seukuran jempol kaki, khusus lemang bambu kecil digunakan untuk ritual adat yang diadatakan di depan rumah tokoh adat atau juru kunci pemakaman puyang burung jauh/putang dulu sebagai makam yang dianggap keramat oleh masyarakat setempat.
} 
Secara sosial tradisi Malemang memiliki makna dan nilai solidaritas sosial (Emal Durkheim), lebih lanjut Durkheim menjelaskan bahwa keseluruhan kepercayaan dan perasaan bersama dalam sebuah masyakat akan membentuk suatu sistem yang tepat dalam pola kehidupan bersama, (Geogre Ritzer, 2012:85). Dalam tradisi Malemang keterlibatan masyarakat adat begitu besar hal itu dapat dilihat dari acara upacara dan berebut lemang dan prosesi lainnya, yang dihadiri tidak hanya dari masyarakat setempat, melaikan dari desa tetangga di Kecamatan Sungai Keruh, juga dihadiri masyarakat Kabupaten Musi Banyuasin, Palembang, ada juga yang dari kabupaten lain, dan juga dihadiri oleh Bupati, Camata, dan seluruh kepala desa.

Nilai kesadaran kolektif telah berlangsung puluhan dan bahkan ratusan tahun telah menjadi bagian dari kehidupan masyarakat Sungai Keruh melalui tradisi Malemang yang diwariskan secara turun-temurun dari generasi ke generasi yang telah membentok pola hubungan dan sistem sosial yang menunjukan bagaimana pola perilaku dalam kehidupan sosial diatur melalui tata aturan norma adat sebagai perwujudan nilai kebersamaan, kohesi sosial, dan juga makna tradisi Malemang mampu memelihara tata nilai, keharmonisan sosial, penyelesaikan konflik yang terjadi masyarakat melalui nilai kearifan budaya lokal, (Sutarto, dkk; 2013).

Seiring waktu berjalan dalam tradisi Malemang terjadi pergeseran dan perubahan sosial dan budaya yang cukup kuat, tradisi Malemang tidak hanya bermakna tradisi ritual semata, namun sekarang telah menjadi destinasi wisata dan aset wisata, dan juga telah manjdi aset sosial dan politik dimana momen ritual tradisi menjadi ajang para calon bupati, legislatif untuk menarik simpati masyarakat. Ditengah pergulatan masyarakat modernisasi dan globalisasi tentu perubahan tatanan sosial budaya dan pola pikir, karena dalam waktu yang bersamaan masuknya budaya baru yang memiliki unsur lebih maju yang berwatak kapitalisme, rasionalitas, pola berpikir baru yang pasti mempengaruhi pola tatanan kehidupan sosial, masyarakat urban sebagai contoh nyata masyarakat modernisasi dimana pola interaksi sosial budaya semakin terisolasi dalam kultur individualisme. Belum lagi berbicara dimensi globalisasi yang merupakan paket dari modernisasi, dimana salah satu tantangan atas gejala globalisasi adalah sekulerisasi yang mampu menerobas ruang batas kultur, agama, sosial, ekonomi, politik dan budaya lokal, sehingga ada semacam gejala rusaknya tatanan sistem nilai budaya, sehingga disinilah urgensi bagaimana peran kearifan budaya lokal menjadi sangat penting dalam melastrasikan penguatan budaya lokal (tradisi malemang), dan tatanan nilai sebagai basis kehidupan sosial budaya di tengah masyarakat modernisasi? 


\section{Metodologi Penelitian}

Penelitian ini merupakan penelitian deskriptif kualitatif dalam perspektif sosiologis budaya, dalam pandangan Bogdan dan Taylor (1975), mendefinisikan metodologi kualitatif sebagai prosedur penelitian yang menghasilakan data deskriptif berupa kata-kata tertulis atau lisan dari orang-orang dan perilaku yang dapat diamati, (Lexy J. Moleong, 2006). Pendekatan ini diarahkan pada latar dan individu tersebut secara holistik (utuh), jadi dalam hal ini tidak boleh mengisolasikan individu atau organisasi ke dalam variabel atau hipotesis, tetapi perlu memandangnya sebagai bagian dari sesuatu keutuhan. Metode pengumpulan data dalam studi ini menggunakan teknik interview terhadap tokoh agama, budaya, kepada desa, stakehorder, dan masyarakat dengan memberikan berberapa pertanyaan yang berkaitan dengan tema penelitian, observasi terhadap ritual dan keterlibatan secara langsung dalam ritual tradisi Malemang dengan mencatat fenomena dan peristiwa secara sistematik, dan dokumentasi berupa data dokumen, photo, peninggalan berupa artefak dan studi historis.

Dilain pihak Kirk dan Miller (Moleong, 2006), mendefinisikan bahwa penelitian kualitatif merupakan tradisi dalam ilmu pengetahuan sosial yang secara fundamental bergantung dari pengamatan pada manusia. Metodologi kualitatif menurut (Denzin dan Lincoln 1987) merupakan penelitian yang mengunakan latar ilmiah, dengan maksud menafsirkan fenomena yang terjadi dan dilakukan dengan jalan melibatkan berbagai metode yang ada. Dalam penelitian kualitatif, menurut Strauss dan Oorbin dalam B Mrowi dan Sudftin (Rusian, 2003), ${ }^{3}$ merupakan jenis penelitian yang menghasilkan penemuan-penemuan yang tidak dapat dicapai dengan menggunakan prosedur statistik atau cara kuantitatif lainnya. Metodologi kualitatif dapat dipergunakan untuk penelitian kehidupan masyarakat, sejarah, tingkah laku, fungsional organisasi, peristiwa tertentu, pergerakan-pergerakan sosial dan hubungan kekerabatan dalam keluarga.

Sehubungan dengan penelitian deskriptif kualitatif, ada beberapa istilah yang digunakan dalam penelitian kualitatif yaitu penelitian atau inkuiri naturalistik atau alamiah, etnografi, interaksionalis simbolik, perspektif ke dalam, etnometodologi, fenomenologis, studi kasus, interpretatif, ekologis, dan deskriptif (Bogdan dan Biklen, 1982) lihat juga (Angel Purwanti, 2013)

\section{Tinjauan Teoritis}

Dalam studi ilmu sosial ada dua pendekatan yang paling populer dibanding pendekatan-pendekatan lain, yaitu pembahan yang menyangkut konflik (teori konflik) dan integrasi (fungsionalisme-struktural). Sudut pendekatan 
tersebut menganggap bahwa masyarakat pada dasarnya terintegrasi di atas dasar kata sepakat para anggotanya akan sistemnilai-nilai kemasyarakat, suatu general agreements yang memiliki kekuatan mengatasi perbedaan pendapat dan kepentingan di antara para anggota masyarakat, (Nasiku, 2010). Lebih jauh fungsionalisme-struktural beranggapan bahwa masyarakat sebagai suatu sistem yang secara fungsional terintegrasi ke dalam satu bentuk equilibrium. Selain itu juga dalam melihat berbagai perubahan sosial budaya dalam dinamika masyarakat modernisasi akan dilengkapi pendekatan teoris perubahan sosial dan sekaligus konflik sosial budaya.

Secara teoritis fungsionalisme struktural sebagaimana yang telah diberkembangkan oleh Parson dan para pengikutnya, dapat kita lihat beberapa anggapan dasar mereka seperti di dalam Pierre L. Van den Berghe (dalam Nasikun, 2010, lihat Parsons, 1991 dan Ritzer, 2012).

a. Masyarakat haruslah dilihat sebagai suatu sistem dari pada bagian-bagian yang saling berhubungan satu sama lain.

b. Dengan demikian hubungan pengaruh mempengaruhi di antara bagianbagian tersebut adalah bersifat ganda dan timbal balik.

c. Sekalipun integrasi sosial tidak pernah tercapai dengan sempurna, namun secara fundamental sistem sosial selalu cenderung bergerak kearah ekuilibrium yang bersifat dinamis; mengganggap perubahan-perubahan yang datang dari luar dengan kencenderungan memelihara agar perubahan-perubahan yang terjadi di dalam sistem tetap berjalan stabil.

d. Sekalipun terjadi disfungsi, ketegangan-ketegangan, penyimpangan terjadi, akan tetapi dalam jangka yang panjang keadaan tersebut akan teratasi melalui proses penyesuaian dan proses institusionalisasi.

e. Perubahan-perubahan di dalam sistem sosial pada umumnya terjadi secara gradual, melalui penyesuaian, dan tidak secara revolusioner, sedangkan unsur-unsur sosial budaya yang menjadi bangunan dasarnya tidak teralalu mengalami perubahan.

f. Pada dasarnya perubahan-perubahan sosial timbul atau terjadi melalui tiga macam kemungkinan; penyesuaian-penyesuaian yang dilakukan oleh sistem sosial tersebut terhadap perubahan-perubahan yang datang dari luar (extra system change); pertumbuhan melalui proses diferensiasi struktural dan fungsional; serta penemuan-penemuan baru oleh anggota masyarakat.

g. Faktor yang paling penting yang memiliki daya mengintegrasikan suatu sistem sosial adalah konsensus di antara para anggota masyarakat mengenai nilai-nilai sosial budaya dan kemasyarakat tertentu dalam kehidupan sosial. 


\section{Konsep Kearifan dan Budaya Lokal}

Dalam pengertian kamus, kearifan lokal (local wisdom) terdiri dari dua kata: kearifan (wisdom) dan lokal (local). Dalam Kamus Inggris Indonesia John M. Echols dan Hassan Syadily, local berarti setempat, sedangkan wisdom (kearifan) sama dengan kebijaksanaan. Secara umum maka local wisdom (kearifan setempat) dapat dipahami sebagai gagasan-gagasan setempat (local) yang bersifat bijaksana, penuh kearifan, bernilai baik, yang tertanam dan diikutioleh anggota masyarakatnya (Sartini, 2003).

Menurut Wagiran (2012), kearifan lokal paling tidak menyiratkan beberapa konsep, yaitu: (1) kearifan lokal adalah sebuah pengalaman panjang, yang diendapkan sebagai petunjuk perilaku seseorang; (2) kearifan lokal tidak lepas dari lingkungan pemiliknya; dan (3) kearifan lokal itu bersifat dinamis, lentur, terbuka, dan senantiasa menyesuaikan dengan zamannya. Dalam perkembangnya kearifan lokal tidak selalu kaku. Sebagai alat dan konsep kearifan lokal melekat sejalan dengan proses perkembangan soaial manusia sesuai konteks sosio- kultural yang melatarinya khususnya faktor historis. Sehingga kearifan lokal sebenarnya selalu ada di dalam setiap realitas masyarakat, melekat dalan sistem tatanan nilai norma tradisi lokal, (Sutarto, dkk. 2013).

Kearifan lokal sangat lekat dengan budaya menurut Kontjaraningrat; bahwa budaya pada prakteknya memiliki tiga wujud yaitu dalam gagasan atau ide, dalam bentuk tata laku dan dalam bentuk artefak budaya. Jika melihat definisi tersebut, kearifan lokal memiliki dimensi yang sangat luas, yaitu berada pada ruang ide/gagasan, ruang praktik, dan ruang fisik. Untuk menggali kearifan lokal di dalam masyarakat tidak boleh melewatkan tiga dimensi tersebut untuk digali lebih dalam. Dalam penelitian ini tentunya akan menyandarkan penggalian data dengan kerangka konsep budaya lokal, (Kholik, 2013).

Menurut Wagiran, dari sisi filosofi dasarnya, kearifan dapat dikategorikan dalam dua aspek, yaitu: a) gagasan, pemikiran, akal budi yang bersifat abstrak; mencakup berbagai pengetahuan, pandangan, nilai serta praktik-praktik dari sebuah komunitas baik yang diperoleh dari generasi sebelumnya dari komunitas tersebut maupun yang didapat oleh komunitas tersebut di masa kini, yang tidak berasal dari generasi sebelumnya, tetapi dari berbagai pengalaman di masa kini.termasuk juga dari kontaknya dengan masyarakat atau budaya lain dalam kontek ini masyarakat modernisasi. b) kearifan lokal yang berupa hal-hal konkret, berupa benda-benda artefak, yang menghiasi hidup manusia, dan bermakna simbolik, (Lihat dalam Kholik, 2013)

Kearifan dan Budaya Lokal adalah pandangan hidup dan ilmu pengetahuan serta berbagai strategi kehidupan yang berwujud aktivitas yang dilakukan oleh masyarakat lokal dalam menjawab berbagai masalah dalam pemenuhan kebutuhan mereka. Semua bentuk pengetahuan, keyakinan, 
pemahaman atau wawasan manusia dalam menjalankan kehidupannya dari berbagai perspektif, seperti politik, ekonomi, sosial, budaya, agama maupun lingkungan.

Kearifan lokal berkaitan dengan kemampuan masyarakat dalam memahami kondisi lingkungan dan alam sekitar, yang kemudian melakukan adaptasi dengan kondisi yang ada. Kearifan lokal adalah pandangan hidup dan ilmu pengetahuan serta berbagai strategi kehidupan yang berwujud aktivitas yang dilakukan oleh masyarakat lokal dalam menjawab berbagai masalah dalam pemenuhan kebutuhan mereka. Dalam bahasa asing sering juga dikonsepsikan sebagai kebijakan setempat "local wisdom" atau pengetahuan setempat "local knowledge"atau kecerdasan setempat "local genious" (Rajab, 2006). Masingmasing masyarakat memiliki kearifan lokal yang menjadi kemampuan adaptasi dalam menjalani kehidupan sehari-hari, dan biasanya akan berwujud dalam bentuk keseimbangan alam maupun sosial menuju harmonisasi, (Yenrizal, 2012).

\section{Tradisi Malemang dan Modernisasi}

Modernisasi selalu melibatkan globalisasi dan berimplikasi pada perubahan tatanan sosial dan intelektual, karena dibarengi oleh masuknya budaya impor ke dalam masyarakat tersebut. Menurut Boeke, ketika budaya impor yang unsur-unsurnya lebih maju, berwatak kapitalis, berhadapan dengan budaya lokal yang berwatak tradisional, terjadi pergulatan antara budaya luar dengan budaya lokal. Pertarungan kedua budaya tersebut tidak selalu berakhir dengan model antagonistik, tetapi unsur yang tersisih akhirnya tidak berfungsi dan digantikan oleh unsur baru yang kemungkinan besar dimenangkan oleh unsur impor. Biasanya, unsur lokal berangsur-angsur menurun dan tidak lagi diminati oleh masyarakat tradisional, (Hammis Syafaq, 2009)

Realitas budaya lokal dan tradisi pada komunitas khususnya yang terjadi pada budaya lokal Malemang di Sungai Keruh, menurut Haris "bahwa tradisi Malemang sudah jauh bergeser dari tahun 1990an sampai sekarang khususnya perubahan kesadaran akan nilai dan tradisi lokal, sehingga tokoh adat dan pak kades tidak terlalu dihargai lagi walaupun tradisi Malemang masih berlangsung, hal itu terjadi menurut pak Haris karena masa sudah modern" (Wawancara Haris, 2013)

Istilah modern secara bahasa berarti baru, kekinian, akhir, up-todate atau semacamnya. Bisa dikatakan sebagai kebalikan dari lama, kolot atau semacamnya. Modernisasi, menurut sebagian ahli, adalah sejenis tatanan sosial modern atau yang sedang berada dalam proses menjadi modern. Bagi ahli lain, modernisasi ditemukan dalam kepribadian individual. Istilah modern juga bisa berkaitan dengan karakteristik. Modernisasi memang sangat luas artinya, 
mencakup proses memperoleh citra (images) baru seperti citra tentang arah perubahan atau citra tentang kemungkinan perkembangan. Batasan-batasan modernisasi seringkali hanya ditekankan pada aspek-aspek perubahan di bidang teknologi dan ekonomi. Akan tetapi, sebagaimana dikemukakan oleh Manfred Halpern, revolusi modernisasi sebenarnya melibatkan transformasi semua sistem yang berlaku sebelumnya dalam masyarakat, baik sistem politik, sosial, ekonomi, intelektual, keagamaan maupun psikologi, (Hammis Syafaq, 2009)

Karakter modernisasi yang rasional, selalu menawarkan hal-hal yang baru, dalam membicarakan modernisasi sebuah proses panjang. Berbicara tradisi Malemang sebagai sebuah kearifan lokal tentu mendapat tantangan besar di tengah arus deras modernisasi dan globalisasi; harus dipahami makna modernisasi secara rinci, modern yang identik hal baru, ide, gagasan, pola pikir, produk; modernitas sebagai sebuah produk kemodernan; modernisme adalah sebuah ideologi kapitalisme, hedonisme, sekulerisme dan identik budaya dan pola hidup barat; dan modernisi sebagai sebuah proses kemoderenan yang sangat identik dengan westernisasi. Ini semua tentu memberikan dampak pada terjadinya perubahan sosial budaya dan tatanan nilai, khususnya dalam tradisi Malemang, dimana perubahan persepsi baik-buruk, pandangan, dan perubahan sistem nilai yang mempengaruhi pola tindakan terjadi, seperti pandangan bapak Arifin "Tradisi Malemang yang merupakan tradisi syukuran pasca panen dan tradisi keselatan tolak balak, saat ini sudah mulai berkurang dilakukan khususnya para anak muda, tradisi-tradisi lokal sudah mulai ditinggalkan" (Wawancara, 2013).

Dewasa ini modernisasi dan globalisasi dua duania yang tidak bisa dipisahkan dengan kehidupan sosial, baik realitas alam nyata ataupun dunia maya (media) dimana perkembanganyang sangat cepat di bidang komunikasi, teknologi, transportasi dan informasi, yang menjadikan dunia semakin sempit karena segala sesuatu semakin mudah dicapai, (Hammis Syafaq, 2009). Proses globalisasi juga terbentuk oleh pertukaran informasi dan budaya dari belahan dunia manapun dengan sangat mudah, sehingga masuknya budaya barat seperti seks bebas, alkoholisme, diskotik, dan kehidupan hedonisme yang begitu kuat, dengan demikian dampaknya akan menggerus tatanan nilai budaya keindonesiaan dan merubah pola budaya, persepsi dan kebutuhan yang lebih instan dan pragmatis sehingga masyarakat lebih mengabaikan proses.

Kaitanya dengan dunia Barat, ada beberapa teori mengenai modernisasi. Daniel Lerner misalnya, beranggapan bahwa modernisasi identik dengan Westernisasi, sekularisasi, demokratisasi dan pada akhirnya liberalisasi. Tetapi ada yang membuat dikotomi antara modernisasi dan Westernisasi, di mana modernisasi lebih bersifat teknologis, sementara Westernisasi lebih berorientasi pada nilai. Selain itu, di dalam beberapa studi tentang sosiologi dikatakan bahwa 
di beberapa wilayah, industrialisasi merupakan bagian dari modernisasi. Artinya, modernisasi berimplikasi pada munculnya industrialisasi. Akan tetapi di beberapa negara lain terjadi sebaliknya, di mana industrialisasi berimplikasi pada modernisasi, (Hammis Syafaq, 2009)

Yang jelas, modernisasi telah membentuk sebuah perubahan yang mendasar tentang tingkah laku dan keyakinan di bidang ekonomi, politik, organisasi social, budaya, agama dan bentuk pemikiran, (Hammis Syafaq, 2009). Lebih lanjut Syafaq menjelaskan, di bidang ekonomi, perubahan bisa dilihat dalam wujud industrialisasi dan pertumbuhan ekonomi, munculnya kebutuhankebutuhan kapital dalam jumlah besar, pertumbuhan sains dan munculnya kelaskelas baru dan mobilisasi sosial. Di bidang politik, ditandai oleh munculnya partai-partai politik, kesatuan-kesatuan dan kelompok-kelompok kepemudaan. Di bidang dimensi sosial, terjadinya perubahan hubungan antar lawan jenis, komunikasi masa, dan urbanisasi. Modernisasi juga menimbulkan difusi normanorma sekuler-rasional dalam kebudayaan.

Peter Berger seorang sosiolog Amerika menyatakan bahwa ada lima pilar modernisasi:

1. Abstraction, yaitu gaya hidup dalam bentuk birokrasi dan teknologi.

2. Futurity, bahwa masa depan menjadi orientasi pokok dalam beraktivitas dan berimajinasi, serta gaya hidup diatur oleh waktu.

3. Individuation, pemisahan individu dari segala rasa entitas kolektif, dan membentuk alinasi.

4. Liberation, bahwa pandangan hidup didominasi oleh pilihan bukan kebutuhan; artinya, segala sesuatu yang di luar kebutuhan, mampu diwujudkan.

5. Secularization, terjadinya kemerosotan di bidang keyakinan keagamaan.

Pemikiran Berger di atas boleh dibilang semuanya benar kalau kita lihat realitas kehidupan masyarakat modern saat ini, gaya hidup semakin konsumerisme, kehidupan semakin teralienasi (terasing dalam keramaian) oleh kemajuan teknologi, daya imajinasi dan dunia maya semakin kuat, pola individual sekamin kuat, dan sekulirisme mendominasi yang diiringi oleh pola rasionalitas ssekamin mendominasi pola pikir masyarakat modern. Sejauh mana tradisi Malemang mampu bertahan, beradaptasi, dan memfilter arus deras kultur modernisasi, jawabannya bisa beradaptasi dan eksistem ditengah modernisasi dengan catatan masyarakat harus memiliki makisme budaya dalam menghadapi perubahan sosial dengan kekutan sistem sosial, nilai, adat serta norma yang secara kontinu terintegrasi dalam proses sosial dengan tujuan menciptakan kohensi dan equilibrium sosial, dan dalam waktu bersamaan memperkuat konsensus sosial. 
Melihat pandangan I Ketut Gobyah dalam "Berpijak pada Kearifan Lokal" dalam http://www. balipos.co.id, 30/09/2012, mengatakan bahwa kearifan lokal (local genius) yang merupakan kebenaran yang telah mentradisi atau ajeg dalam suatu daerah. Kearifan lokal merupakan perpaduan antara nilai-nilai suci firman Tuhan dan berbagai nilai yang ada. Kearifan lokal terbentuk sebagai keunggulan budaya masyarakat setempat maupun kondisi geografis dalam arti luas. Kearifan lokal merupakan produk budaya masa lalu yang patut secara terus-menerus dijadikan pegangan hidup. Meskipun bernilai lokal tetapi nilai yang terkandung didalamnya dianggap sangat universal, kekuatan nilai, kearifan, tradis Malemang dalam menghadapi budaya masyarakat modern yang lebih rapuh dan rasional menjadi tantang yang besar bagi eksisnya tradisi, dalam pandangan pak Rafik "bahwa tantangan terbesar tradisi lokal Malemang saat ini adalah memelihara, menjaga dan melestarikan karena ketidak pedulian masyarakat terhadap budaya lokal dan kesadaran semakin berkurang karena kalah bersaing dengan kemajuan teknologi dan hal baru” (Wawancara Pak Rafik, 2013).

Berangkat dari konsep kearifan dan budaya lokal di atas bahwa pandangan hidup dan ilmu pengetahuan serta berbagai strategi kehidupan yang berwujud aktivitas yang dilakukan oleh masyarakat lokal dalam menjawab berbagai masalah dalam pemenuhan kebutuhan mereka. Semua bentuk pengetahuan, keyakinan, pemahaman atau wawasan manusia (local knowledge) Clifford Geertz (2003) dalam menjalankan kehidupannya dalam berbagai perspektif, seperti politik, ekonomi, sosial, budaya, agama maupun lingkungan. Konsep lokalitas tardisi Malemang dalam kehidupan masyarakat "adat" adalah satu sistem sosial yang kompleks yang merupakan pola yang terintitusionalisasi menjadi berbagai dari aktivitas sosial, budaya, agama dan politik lokal yang mencirikan pola relasi yang khas, dengan muatan tradisi, norma da adat yang menjadi identitas budaya, etnit yang "lokal".

Kearifan lingkungan atau kearifan lokal masyarakat (local wisdom) sudah ada di dalam kehidupan masyarakat semenjak zaman dahulu mulai dari zaman pra-sejarah hingga saat ini, kearifan lokal merupakan perilaku positif manusia dalam berhubungan dengan alam dan lingkungan sekitarnya yang dapat bersumber dari nilai-nilai agama, adat istiadat, norma-norma sosial, petuah nenek moyang atau budaya setempat (Wietoler, 2007), kekuatan Tradisi Malemang yang terbangun secara alamiah dalam waktu yang panjang sejak zaman kolonial Bekanda di masyarakat Sungai Keruh untuk dapat beradaptasi dengan lingkungan masyarakat modernisasi yang cenderung lebih liberal dan sulit untuk dikendalikan secara kultural khususnya. Namun dengan pola perilaku yang positif dengan kekuatan sistem perilaku yang dapat menjaga nilai luhur, agama, adat istiadat dan 
norma akan mampu membendung proses sosial kemaderenan yang membawa kepada perubahan sosial yang tidak beraturan.

\section{Sistem Pengetahuan, Teknologi dan Budaya Lokal}

Sistem pengetahuan atau pengetahuan lokal (Clifford Geertz, 2013), bagi masyarakat lokal adalah menjadi identitas kolektif dan bagian dari aktivitas perilaku dalam masyarakat sebagai penuntun perilaku dalam berbagai aspek, sehingga peran pengelaman, nilai moral, etika, adat melebur menjadi sistem dan pola berpikir masyarakat adat yang menuntu kepada kehormonisan, penyelesaian masalah yang dihadapi, memlihara karmonisan dan kohesi sosial. Namun kearifan lokal yang sesungguhnya akan mendapat ujian yang ketika kemajuan teknologi merambah ke batas-batas wilayah, kultur, nilai dan agama melalui berbagai macam kemajuan teknologi; televisi, internet, kebebasan informasi, sehingga memungkinkan arus transformasi budaya dan berbagai perilaku turut menggerus nilai-nilai kearifan dan budaya lokal. Lalu bagaimana melalui pengetahuan, budaya dan kearifan lokal tetap dipertahankan tradisi Malemang.

Terkait hal itu. Menurut Pak Andi,"terkait teknologi kalau dulu disini (Sungai Keruh) setiap rumah belum ada TV, kulkas, parabola, listrik, mobil masih jarang dan jalan masih belum aspal, tetapi sekarang semuanya sudah ada di kampung dan itu membuat perilaku berubah, bahkan seks bebas, narkoba sudah masuk di kampung” (Wawancara Pak Andi, 2013). Menyongsong masyarakat industri modernisasi harus memiliki mekanisme budaya yang kuat untuk bisa selaras dengan perkembangan zaman yang sedemikian cepat berubah, maka baik secara organisasi ataupun institusi sosial harus kuat dan terintegrasi dengan solidaritas yang kuat antar elemen sosial dan teknologi yang membangun.

\section{Strategi Budaya dan Prinsif-prinsif Kearifan Lokal}

Kearifan tradisi atau kearifan lokal yaitu semua bentuk tradisi, keyakinan, pemahaman atau wawasan serta adat kebiasaan, atau etika yang menuntun perilaku manusia dalam kehidupan di dalam komunitas atau kelompok sosial masyarakat (Keraf, 2002). Jadi kearifan tradisional ini bukan hanya menyangkut pengetahuan dan pemahaman masyarakat adat tentang manusia dan bagaimana relasi yang baik di antara manusia, melainkan juga menyangkut pengetahuan dan pemahaman, dan adat kebiasaan tentang manusia, alam dan bagaimana relasi di antara semua penghuni semua komunitas ekologis ini harus dibangun.

Menurut Ardhana (2005), kearifan lokal dapat dipahami sebagai perilaku bijak yang selalu menggunakan akal budi, pengelaman dan pengetahuan yang dimiliki masyarakat dalam suatu wilayah tertentu dan sekaligus menjadi strategi budaya dalam menghadapi lingkungan sosial. Dalam kearifan lokal ada karya atau 
tindakan manusia yang bersifat bersejarah, yang masih diwarisi oleh masyarakat setempat. Perilaku bijak ini pada umumnya adalah tindakan, kebiasaan atau tradisi, dan cara-cara masyarakat setempat yang menuntun untuk hidup tentram, damai dan sejahtera. Sejalan dengan itu pula, Sunaryo dan Laxman (2003), menambahkan bahwa pengetahuan lokal yang sudah demikian menyatu dengan sistem kepercayaan, norma dan budaya, dan diekspresikan di dalam tradisi dan mitos yang dianut dalam jangka waktu cukup lama ada kemungkinan akan menjadi kearifan lokal.

Dalam Balipos terbitan 4 September 2003 memuat tulisan "Pola Perilaku Orang Bali Merujuk Unsur Tradisi”, antara lain memberikan informasi tentang beberapa fungsi dan makna kearifan lokal, (Sartini, 2004) yang bisa menjadi strategi budaya dan prinsif nilai sebaga pelestarian budaya yaitu:

1. Berfungsi untuk konservasi dan pelestarian sumber daya alam.

2. Berfungsi untuk pengembangan sumber daya manusia, misalnya berkaitan dengan upacara daur hidup.

3. Berfungsi untuk pengembangan kebudayaan dan ilmu pengetahuan, misalnya pada upacara saraswati, kepercayaan dan pemujaan pada pura Panji.

4. Berfungsi sebagai petuah, kepercayaan, sastra dan pantangan.

5. Bermakna sosial misalnya upacara integrasi komunal/kerabat.

6. Bermakna sosial, misalnya pada upacara daur pertanian.

7. Bermakna etika dan moral, yang terwujud dalam upacara Ngaben dan penyucian roh leluhur.

8. Bermakna politik, misalnya upacara pasca panen dan kekuasaan patron Client. Dari penjelasan fungsi-fungsi tersebut tampak betapa luas ranah keraifan lokal, mulai dari yang sifatnya sangat teologis sampai yang sangat pragmatis dan teknis.

\section{Kearifan Lokal sebagi Milik Komunitas}

Kearifan lokal sebagi milik komunitas dapat dipahami bahwa sistem pengetahuan, norma, adat dan etika sebagai way of life atau sebagai sistem pengetahuan lokal yang menjadi nilai-nilai solidaritas, integrasi dan kohesi yang bersifat kontruktif dalam membangun kehidupan masyarakat, komunitas, ekologi dan keharmonisan. Sudah banyak studi yang menunjukkan bahwa masyarakat adat di Indonesia secara tradisional berhasil menjaga dan memperkaya keanekaragaman hayati karena sebagian besar masyarakat adat masih memiliki sistem-sistem lokal dalam pengelolaan sumberdaya alam yang diwariskan dan ditumbuh-kembangkan secara terus-menerus secara turun-temurun (Nababan, 2003).

Kearifan tradisional atau kearifan lokal mengandung tiga unsur penting. Pertama, nilai religius dan etika social yang mendasari praktek-praktek pengelolaan sumber daya hayatinya. Kedua, norma/aturan adat, yang mengatur hubungan antar komunitas dan lingkungan alamnya. Ketiga, pengetahuan lokal 
dan ketrampilan yang diperoleh dari pengalaman empirik berpuluh-puluh bahkan beratus-ratus tahun mengelola sumber daya hayati dan lingkungannya. Kesemuanya ini merupakan satu kesatuan system yang melandasi tatanan kehidupan social, budaya, ekonomi dan politik komunitas petani masyarakat adat. Sumber daya hayati merupakan bagian dari kebudayaan komunitas adat. Pemanfaatan dan kelestarian sumber daya hayati ini sangat erat kaitannya dengan kearifan tradisional yang dimiliki oleh komunitas tersebut

Pandangan Nyoman Sirtha dalam "Menggali Kearifan Lokal untuk Ajeg Bali" dalam http://www.balipos.co.id, bentuk-bentuk kearifan lokal dalam masyarakat dapat berupa: nilai, norma, etika, kepercayaan, adat-istiadat, hukum adat, dan aturan-aturan khusus. Oleh karena bentuknya yang bermacam-macam dan ia hidup dalam aneka budaya masyarakat, maka fungsinya menjadi bermacam-macam sehingga secara holistik mampu meberikan tuntunan, pola aturan dalam segenap perilaku manusia sehingga keharmonisan, kedamaian dan dalam aspek kehidupan mampu menjadi ruh atau spirit dan sekaligus menjadi solusi atas berbagai masalah dalam kehidupan masyarakat, integrasi sosial dan integrasi bangsa.

Haryati Soebadio mengatakan bahwa local genius adalah juga cultural identity, identitas atau kepribadian budaya bangsa yang menyebabkan bangsa tersebut mampu menyerap dan mengolah kebudayaan asing sesuai watak dan kemampuan sendiri (Ayatrohaedi, 1986:18-19). Sementara Moendardjito (dalam Ayatrohaedi, 1986:40-41) mengatakan bahwa unsur budaya daerah potensial sebagai local genius karena telah teruji kemampuannya untuk bertahan sampai sekarang, dengan ciri-cirinya berikut:

1. mampu bertahan terhadap budaya luar

2. memiliki kemampuan mengakomodasi unsur-unsur budaya luar

3. mempunyai kemampuan mengintegrasikan unsur budaya luar ke dalam budaya asli

4. mempunyai kemampuan mengendalikan

5. mampu memberi arah pada perkembangan budaya

\section{Kearifan Lokal sebagai Aktivitas Moral}

Masyarakat adat memiliki budaya sebagai proses mental, perasaan, simbolisme yang merupakan produk budaya (Cifford Geertz, 2003), sebagai konstitusi dan institusi budaya dan melihat sistem sosial, ekonomi, lingkungan dan spiritual yang saling tergantung satu sama lain. Mereka membuat kontribusi yang berharga untuk dunia dengan pengetahuan tradisional mereka dan pemahaman mereka tentang pengelolaan ekosistem, lingkungan, sosial, dan tanggung jawab moral. Tetapi masyarakat adat juga seringkali merupakan kelompok yang paling rentan, terpinggirkan dan kurang beruntung dalam kehidupan manusia. Namun yang penting harus dipastikan bahwa suara mereka 
(masyarakat adat atau kearifan lokal) di dengar, hak-hak mereka dihormati, dan kesejahteraan mereka dipastikan tidak hilang.

Dalam komunitas sosial etika dan moral dapat diberlakukan, jadi yang disebut sebagai norma dan nilai moral hanya dibatasi keberlakuannya bagi manusia dalam segala aktivitas khususnya dalam kehidupan budaya lokal. Dalam pemahaman ini, hanya manusia merupakan pelaku moral yaitu makhluk yang mempunyai kemampuan untuk bertindak secara moral berdasarkan akal budi dan kehendak bebasnya, sehingga etika tidak berlaku bagi makhluk lain diluar manusia (Keraf, 2003). Cara bertindak berdasarkan landasan moral itulah yang menjadi ciri khas dari manifestasi aktivitas kearifan lokal

Memahami kearifan lokal dapat dilakukan melalui pendekatan struktural, cultural dan fungsional (Ardhana, 2005). Menurut perspektif struktural, kearifan lokal dapat dipahami dari keunikan struktur sosial yang berkembang di lingkungan masyarakat yang dapat menjelaskan tentang institusi atau organisasi sosial serta kelompok sosial yang ada. Sedangkan menurut pendekatan kultural, kearifan lokal adalah berbagai nilai yang diciptakan, dikembangkan, dan dipertahankan masyarakat yang menjadi pedoman hidup mereka. Termasuk sebagai mekanisme dan cara untuk bersikap, bertingkah, dan bertindak yang ditungkan dalam suatu tatanan sosial.

Terdapat lima dimensi kultural tentang kearifan lokal yaitu; (1) Pengetahuan lokal,karakter keunikan lokal, dan pengetahuan dan pengelaman masyarakat dalam menghadapi persoalan; (2) Budaya lokal yaitu yang berkaitan dengan unsur-unsur kebudayaan yang telah terpola dalam tradisi lokal yang meliputi sistem nilai, bahasa, tradisi dan teknologi; (3) Keterampilan lokal adalah keahlian atau kemampuan masyarakat setempat untum menerapkan pengetahuan yang dimiliki; (4) Sumber lokal yaitu sumber yang dimiliki utuk memenuhi kebutuhannya dan melaksanakan fungsi-fungsi utamanya; dan (5) Proses sosial lokal, berkaitan bagaimana masyarakat lokal menjalankan fungsi-fungsinya, sistem tindakan sosial yang dilakukan, tata hubungan sosial dan control sosial yang ada. Menurut pendekatan fungsional, kearifan lokal dapat dipahami bagaimana masyarakat melaksanakan fungsi-fungsinya, yaitu fungsi adaptasi, integrasi, pencapaian tujuan dan pemeliharaan pola. Contoh dalam hal adaptasi terhadap era globalisasi (televisi, akulturasi, internet, dll).

Kearifan lokal seperti nilai-nilai kemanusiaan, kebersamaan, persaudaraan, dan sikap ketauladanan bisa menjadi modal sosial yang efektif dalam menjalain, memelihara hubungan harmoni dalam kehidupan sosial, namun arus modernisasi dan globalisasi ikut menggoyahkan pondasi nilai lokal yang selamam ini menjadi pemelihara (kontrol sosial) mulai banyak terkikis di dalam lingkungan budaya masyarakat. Dahulu di masyarakat pedesaan atau lokal di Sumatera Selatan beragam tradisi yang memuat nilai solidaritas sosial, mislanya saat ada hajatan 
pernikahan masyarakat akan sangat senang bila diajak bergotong royong dalam format sosio-kultur, baik melalui tradisi musik-musik lokal, pola relasi informal/tradisional, perkumpulan yang distukan oleh ikatan nilai lokal seperti;

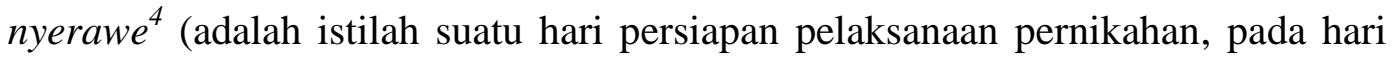
itu seluruh warga desa dan bahkan satu kecamatan datang untuk membantu yang (tuan gawe) dan hal dilakukan tanpa ada paksaan, melainkan hanya kerelaan hati dan kuatnya rasa persaudaraan.

\section{Budaya}

Budaya adalah bahwa keseluruhan kompleks yang mencakup pengetahuan, kepercayaan, seni, moral, hukum, adat dan setiap kemampuan lain dan kebiasaan yang diperoleh manusia sebagai anggota masyarakat. Budaya sering juga disebut sebagai identitas kolektif, karena segenap totalitas sosial, budaya, adat dan nilai-nilai lokal menyatu dan terintegrasi dalam tatanan hubungan sosial, simbolik, persamaan, persaudaraan, dan bahkan sistem berpikir.

Dalam kehidupan agama saat ini yang menjadi tantangan besar adalah membangun pola relasi mutual understading, tolerasi dan sekaligus mendamaikan antara tradisi agama, dan nilai-nilai lokal yang sekaligus membumikan nilai kedamaian yang hakiki. Karena selama ini interrelasi agama dan eksistensi culture belum berjalan secara harmonis dalam kehidupan sosial (Sutarto, 2012), sehingga seringkali muncul konflik-konflik yang bermuatan agama, budaya dan etnik yang sulit dihindari. Pada hal agama merupakan sumber nilai, tradisi, yang terintegrasi dalam tatanan kehidupan sosial yang sudah terinstitusi ke dalam berbagai unsur sosial, budaya, adat, tradisi dan nilai-nilai lokal lainnya sebagai nilai universal.

Kearifan lokal dapat diperoleh diwarisi secara turun-temurun, sehingga bentuk kearifan lokal dapat dilihat melalui pendekatan kultural yaitu terdiri dari pengetahuan lokal, budaya lokal, keterampilan lokal, sumber lokal dan proses sosial (Ilham A. Pardede, 2008). Contohnya aspek pengelolaan sumberdaya air yang berkelanjutan mensyaratkan adanya fungsi ekonomi, ekologi, dan sosial yang saling berhubungan satu sama lain. Untuk meningkatkan fungsi ekologi maka upaya yang dilakukan yaitu menitikberatkan pada terjaganya kelestarian lingkungan atau kawasan sumber air. Fungsi sosial budaya diupayakan untuk semakin melibatkan peran serta masyarakat, terutama masyarakat sekitar kawasan sumber air. Disamping itu sebagai fungsi ekonomi dimana pengelolaan sumber daya sebagai penyangga keberlanjutan sistem produksi, konservasi dan

\footnotetext{
${ }^{4}$ Nyerawe adalah istilah di masyarakat Sungai Keruh Musi Banyuasin, dan Tuan Gawe adalah tuan ruah yang mempunyai hajat. Dalam masyarakat lokal yang mempunyai hajat biasanya sangat berperan secara sosial, walaupun di sisi lain yang ikut membantu akan tergantung sejauh mana yang punya hajat sering membantu masyarakat lain, solidaritas, dan kohesi sosial menjadi nilai penting dalam tradisi lokal yang menjadi sistem bersama dalam kehidupan sosial.
} 
pendayagunaan kekayaan yang terkandung di dalamnya serta untuk penggunaan secara terpadu, hal ini dapat ditopang dengan kearifan lokal.

Kearifan merupakan seperangkat pengetahuan yang dikembangkan oleh suatu kelompok masyarakat setempat (komunitas) yang terhimpun dari pengalaman panjang menggeluti alam dalam ikatan hubungan yang saling menguntungkan kedua belah pihak (manusia dan lingkungan) secara berkelanjutan dan dengan ritme yang harmonis. Dengan demikian, kearifan lingkungan (ecological wisdom) merupakan pengetahuan yang diperoleh dari abstraksi pengalaman adaptasi aktif terhadap lingkungannya yang khas. Pengetahuan tersebut diwujudkan dalam bentuk ide, aktivitas dan peralatan. Kearifan lingkungan yang diwujudkan ke dalam tiga bentuk tersebut dipahami, dikembangkan, dipedomani dan diwariskan secara turun-temurun oleh komunitas pendukungnya. Sikap dan perilaku menyimpang dari kearifan lingkungan, dianggap penyimpangan (deviant), tidak arif, merusak, mencemari, mengganggu dan lain-lain (Alvi Syahrin, 2011). Kearifan lingkungan dimaksudkan sebagai aktivitas dan proses berpikir, bertindak dan bersikap secara arif dan bijaksana dalam mengamati, mamanfaatkan dan mengolah alam sebagai suatu lingkungan hidup dan kehidupan umat manusia secara timbal balik. Kesuksesan kearifan lingkungan itu biasanya ditandai dengan produktivitas, sustainabilitas dan equtablitas atau keputusan yang bijaksana, benar, tepat, adil, serasi dan harmonis. Kearifan lokal, masyarakat adat, tradisional dan modern inilah key word yang sangat penting dalam memperkuat eksistensi, intergasi social buadaya antar unsur nilai, sistem, tradisi sehingga dapat membentuk integrasi nasional ditengah masyarakat yang majemuk, pluralitas dan multikulturalisme dan sekaligus dapat menghadapi tantangan masyarakat modern.

\section{Kesimpulan}

Sebagai penutup dan kesimpulan singkat studi ini ada beberap point yang harus kita pahami dalam kehidupan sosial masyarakat lokal, kearifan budaya dan tardisi Malemang dalam menghadapi masyarakat modernisasi sebagai wujud keberlangsungan dan eksistensi tradis lokal dan penguatan kearifan budaya sehingga intergrasi sosial, keharmonisan, dan solidaritas sosial yang menjadi ciri khas masyarakat adat dan makna tradisi Malemang.

Petama, Penerapan nilai-nilai kerjasama dalam kehidupan sosial, khususnya dalam berbagai aktivitas kemasyarakat sebagai basis nilai dan sekaligus modal sosial dalam rangka merajut intergras dan kohesi sosial ditengah masyarakat modernisasi dan globalisasi. Kedua, Karena kesejatian hidup bersama dalam tradisi lokal, komunal ataupun masyarakat adat menjadi basis spirit nasionalisme penguatan lokalitas, penghargaan terhadap budaya, etnik, pluralitas, 
multikultural dan keharmonisan, dalam bingkai yang terintegrasi secara masif diharapkan kekuatan budaya lokal mampu menopang pembanguna bangsa. Ketiga, Nilai-nilai kearifan lokal dan tradisi Malemang juga bisa di implementasi dalam berdemokrasi, yaitu adanya ruang publik baik lokal, kota maupun nasional yang memungkinkan setiap elemen bangsa (masyarakat lokal, awam, pemuda, birokrat ataupun kaum terdidik) memiliki ruang untuk berbincang perihal persoalan sosial, tradisi, budaya, politik, kepentingan, aspirasi dan kesejahteraan sebagai kebutuhan hidup bersama dalam tatanan nilai yang arif. Keempat, Menjaga pelestarian lingkungan sosial, budaya, melalui kearifan lokal dengan sistem pengetahuan lokal, sumberdaya lokal, proses lokal, dan budaya lokal mampu menjadi nilai, norma dan adat yang memiliki ruh dan spirit dalam menciptakan suasana ekologis yang harmoni, tanpa berperilaku yang bertentangan dengan nilai kearifan walaupun hidup di zaman moderniasi, sehingga alam atau lingkungan bisa menjadi tempat yang menyejukkan, karena jauh dari bencana seperti banjir, polusi, penyakit dan sebagainya. Kelima, Kerukunan adalah bingkai yang dinamis baik antar etnik, suku bangsa, agama, dan berbagai kepentingan, dengan spirit integrasi, toleransi, dialog dan mutual understanding mampu melahirkan kesejatian harmoni, salah satunya nilai kearifan lokal mendaji basis nilai dalam relasi kemasyarakat dan kebangsaan.

\section{Referensi:}

Adimihardja, Kusnaka. 2004. Sistem Pengetahuan dan Teknologi Lokal. Bandung: Humaniora

Geertz, Clifford. 2003. Pengetahuan Lokal. Yogyakarta: Merapi Rumah Penerbit

Geertz, Clifford. 1983. Abangan, Santri, Priyayi Dalam Masyarakat Jawa. Jakarta: PT. Dunia Pustaka Jaya

Keraf, Sonny. A. 2010. Etika Lingkungan Hidup. Jakarta: Kompas

Moleong, Lexy J. 2006. Metodologi Penelitian Kualitatif, Bandung: PT Remaja Rosdakarya

Nasikun. 2010.Sistem Sosial Indonesia. Jakarta: PT. Rajagrafindo Persada

Pardede, Ilham Akbar, dkk. 2008. Kearifan Lokal Dalam Mewujudkan Pengelolaan Sumberdaya Air yang Berkelanjutan. Bogor: IPB 
Purwanti, Angel. Penataan dan Peningkatan Infrastruktur Sebagai Salah Satu Strategi Komuniaksi Dinas Pariwisata dan Kebudayaan Kota Batam Dalam Visit Batam, Jurnal Charta Humanika Vol. 1 No. 1 Desember 2013

Ridwan, Nurma Ali. Landasan Keilmuan Kearifan Lokal, dalam Jurnal Studi Islam dan Budaya, Vol. 5 No. 1 Januari-Juni 20007

Ritzer, George dan Douglas J. Goodman. 2012. Teori Sosiologi; Dari Teori Sosiologi Klasik sampai Teori Sosial Postmodern. Yogyakarta: Kreasi Wacana

Sutarto, Dendi. 2011. Dinamika Politik Perempuan di Indonesia. Yogyakarta: Samudra Biru

Sutarto, Dendi. Mendialogkan Agama, Budaya dan Kerifan Lokal dalam Perspektif Sosiologi Agama. Jurnal Sosiologi Unsri, Volume 15, nomor 1 Januari-Juli 2012

Sutarto, Dendi. 2012. Sistem Sosial Budaya Masyarakat Sumatera Selatan Kajian Sosiologi, dalam Nurhadi Rangkuti, Melacak Identitas Masyarakat Sumatera Selatan. Palembang: Penerbit Balai Arkeologi Palembang

Sutarto, Dendi, dkk. 2013. Model Penyelesaian Konflik Berbasis Kearifan Lokal"Tepung Tawar" Pada Komunitas Talang Sejemput Lahat Sumatera Selatan. Palembang: Laporan Penelitian Fundamental Universitas Sriwijaya (tidak diterbitkan).

Sutarto, Dendi, dkk. Kapitalisasi Ritual, Negara dan Tradisi Lokal Gunung Kawi Kabupaten Malang Jawa Timir. Jurnal Politik dan Kabijakan Publik FISIP Universitas Riau Kepulauan, 2015

Sartini, Menggali Kearifan Lokal Nusantara Sebuah Kajian Filsafati, Jurnal Filsafat, Nomor 2 Jilid 37, Agustus 2004

Yenrizal. Kearifan Lokal dan Nilai Demokrasi Lokal Masyarakat Sumatera Selatan. Jurnal Sosiologi Unsri, Volume 15, nomor 1 Januari-Juli 2012

Suhelmi, Ahmad. 2007. Pemikiran Politik Barat. Jakarta: PT Gramedia Pustaka Utama

Internet

Alvi Syahrin, Kearifan Lokal Dalam Pengelolaan Lingkungan Hidup Pada Kerangka Hukum Nasional, http://alvisyahrin.blog.usu.ac.id/kearifan-lokaldalam-pengelolaan-lingkungan-hidup-pada-kerangka-hukum-nasional, di akses 1 Oktober 2012 
http://www.ifad.org/english/indigenous/index.htm, Indigenous peoples; valuing, respecting and supporting diversity, diakses 1 Oktober 2012

Gobyah, I Ketut "Berpijak pada Kearifan Lokal” dalam http://www. balipos.co.id, $30 / 09 / 2012$

Syafaq, Hammis Masyarakat Islam dan Tantangan Modernisasi, dalam http://pesantren-iainsa.blogspot.co.id/2009/02/normal-0-false-falsefalse.html 
